\title{
Imparare dalla rappresentazione digitale del paesaggio, tra suggestioni 'romantiche' e rigore matematico
}

Matteo Cavaglià

\section{Abstract}

Una delle maggiori potenzialità dei moderni strumenti informatici di rappresentazione, è quella di consentire una comunicazione sempre più efficace tra discipline diverse. Di rimando, la rappresentazione digitale del territorio può attingere a esperienze maturate in altri campi di indagine, ampliando le proprie possibilità di mettere a sistema modelli sempre più raffinati della realtà fisica rappresentata. In questo contesto una delle metodologie più interessanti attualmente disponibili è caratterizzata dagli strumenti BIM, i quali awantaggiandosi della capacità di codificare informazioni maggiori a quelle necessarie per la mera visualizzazione, rendono ciascun oggetto rappresentato un contenitore digitale di una infinita serie di informazioni spaziali, materiali, economiche, temporali, e via dicendo, caratterizzanti la natura e le proprietà dell'oggetto in questione. Uno degli attuali campi in cui questi strumenti possono ancora a mio avviso progredire è però quello della definizione dell'ambiente naturale. A questo riguardo, un valido ausilio per interfacciarsi con questa tipologia di studi territoriali può provenire dal campo della tradizionale rappresentazione artistica del paesaggio, anche trattandola in chiave digitale.

Parole chiave

architettura del paesaggio, analisi del progetto, BIM, modellazione, analisi ambientale.

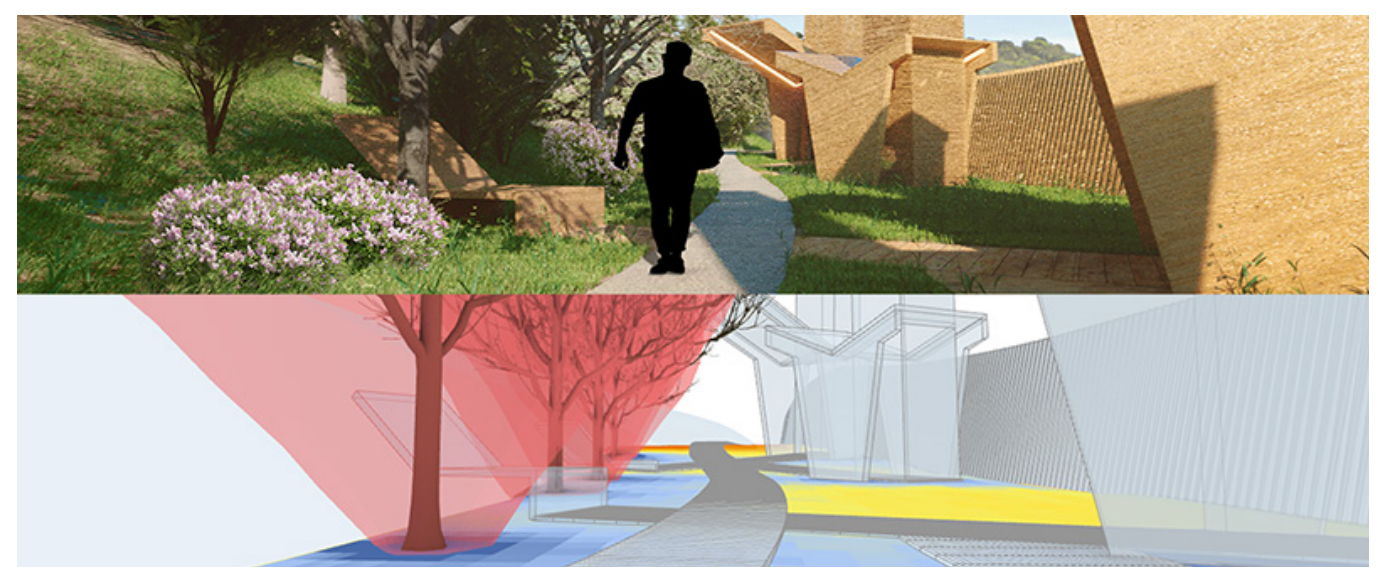




\section{L'interscambio dati, tra reale e virtuale, ai fini della rappresentazione}

Penso che la grafica digitale, in particolare quella specializzata nella rappresentazione realistica, sia in grado di esercitare grande fascino, soprattutto sulle giovani generazioni interessate al mondo della rappresentazione. Seppur sia senz'altro presente una certa amarezza nel constatare che l'approfondimento di queste tematiche talvolta porti a trascurare una certa componente analogica del disegno, ritengo però che queste due metodologie non siano in conflitto, ma che anzi si alimentino dello stesso identico desiderio di conoscenza del mondo e delle sue parti.

Questo è ancora più vero nel campo della rappresentazione del territorio dove, evitando di soffermarsi su ovvie differenze operative tra la via tradizionale e quella digitale, a mio avviso non esistono sostanziali divari nell'approccio verso la realtà fisica in esame. Anzi, come i pittori del passato sfruttavano la rappresentazione artistica anche come laboratorio per la formulazione di teorie geometriche, matematiche e naturalistiche, di fatto generando l'influenza trasversale di saperi necessaria per avere una migliore comprensione del mondo, così anche oggi è possibile sfruttare in modo creativo i mezzi digitali.

Istintivamente un simile approccio non viene associato a questo tipo di ambiente, in quanto apparentemente ben inquadrato sotto il profilo dei software. II rapporto iniziale con essi può sembrare molto rigido, dato che per quanto efficace nella propria area di competenza, ciascun software risulta a prima vista incapace di soddisfare richieste anche di poco diverse da quelle specifiche per cui è stato progettato. Questo limite è in realtà illusorio, e anzi la capacità più eccezionale dei sistemi informatici è la possibilità di mettere in comunicazione differenti tipi di elaborati e quindi diversi ambiti disciplinari. Seppur ogni informazione digitale venga a noi mostrata nel modo in cui ci aspettiamo che si presenti: ad esempio un suono sarà riprodotto come suono, e un'immagine come immagine; dal punto di vista del sistema informatico tutti i dati sono ugualmente codificati in forma di sequenze di valori binari. Ciò che differenzia la presentazione è il 'vocabolario' usato per leggere queste informazioni, perciò cambiandone la chiave di lettura è possibile mostrare i dati in altra forma. In linea di principio ad esempio, si può allora visualizzare un suono come immagine, o riprodurre un'immagine come suono. Questo tipo di trasformazioni permette anche la comunicazione tra diversi software, cioè tra diversi campi operativi, colmando le lacune di uno strumento attraverso il supporto di un altro. L'uso dei mezzi informatici non è quindi da considerarsi un 'assolo', ma bensi un"orchestra', in cui diversi mezzi interagiscono attingendo dal medesimo spartito, nella fattispecie del dato informatico.

Anche la rappresentazione digitale del territorio può arricchirsi di questa possibilità, attingendo in modo sinergico ad esperienze maturate in diverse aree di indagine, generando così molto di più della mera rappresentazione visuale di un paesaggio, seppur la presentazione finale possa richiamare quel tipo di esperienza.

La mia formazione d'architetto ha veicolato il mio rapporto con queste tematiche in un'ottica improntata all'utilità progettuale degli elaborati grafici. Dal punto di vista dello studio del territorio però, credo che ancora oggi la sensibilità dell'architetto possa positivamente contaminarsi, assimilando l'accezione quasi artistica, seppur in modo diverso da altre figure professionali.

\section{La 'materialità' della rappresentazione digitale}

Ritengo che la rappresentazione digitale di un paesaggio operi attraverso due tipologie di canali, ciascuno focalizzato in modo specifico verso un aspetto dello spazio reale.

Il primo tratta la dimensione metrica del luogo, potremmo definirla come una rappresentazione analitica, ed è una via che non ricerca il realismo grafico ma la correttezza dimensionale e geometrica. Si tratta proprio della tipologia di rappresentazione territoriale utilizzata per misurare e rappresentare lo spazio, e in particolare utile ad architetti e ingegneri per simulare in modo preciso l'influenza dei propri progetti sulla realtà.

II secondo invece persegue la via del maggior realismo possibile, ricostruendo tridimensio- 
Fig. I. Questa immagine mostra il paragone di un campione territoriale realizzato sotto forma modello metrico analitico e modello realistico. nalmente non solo la geometria, ma anche la materialità di un territorio, cioè il rapporto degli oggetti con il loro impatto percettivo, sostanzialmente affidato al colore e al modo di riflettere la luce (fig. I).

Ebbene è proprio la rappresentazione realistica a destare spesso il maggior interesse, e in essa ritroviamo anche il maggior grado di punti di contatto con altre discipline. Rappresentare realisticamente la realtà infatti, includendo anche gli aspetti non visibili, chiama in causa una serie di conoscenze, di fatto estese quanto la realtà stessa. Queste circostanze, considerate alla luce della capacità innata dell'ambiente informatico di collegare ambiti diversi, può portare l'utente verso approcci inconsueti.
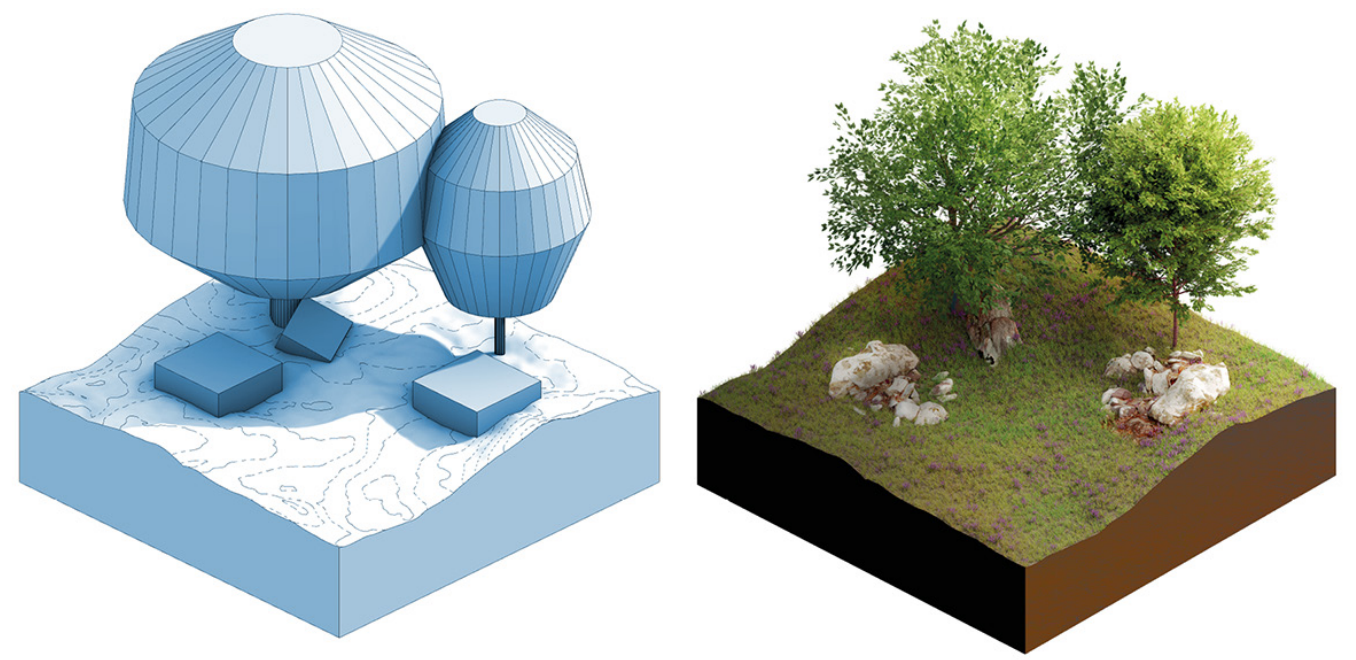

A proposito, uno dei concetti trasmessi inconsapevolmente attraverso l'uso di questi strumenti, riguarda l'utilizzo della statistica a supporto di una modellazione di carattere naturalistico della rappresentazione. La statistica è una chiave di lettura a mio avviso meravigliosa, per comprendere e sfruttare numerosi aspetti della realtà. Non per niente la scienza afferma che in un certo senso la statistica dà fondamento stesso della realtà [Vulpiani 20 I8]. L'uso di sistemi statistici, o pseudo-statistici, in una rappresentazione digitale realistica è d'altra parte un fatto acquisito. Uno dei modi prevalenti attraverso cui si manifestano è attraverso l'uso di immagini in scala di grigi chiamate 'mappe'. Proprio come avviene per le mappe, tali immagini possiedono informazioni sulla loro superficie, che in questo caso possono essere lette in chiave probabilistica. Ciascun pixel della mappa codifica lo stato dell'area su cui sarà proiettato, se il pixel è nero il fenomeno associato avrà una probabilità dello $0 \%$ di verificarsi, al contrario se il pixel è bianco sarà del $100 \%$, mentre valori intermedi determinano una sovrapposizione degli eventi in base al valore percentuale specifico [McDermott 20 I8]. Le mappe trovano ad esempio applicazione nella codifica della riflessione luminosa sintetizzando la sovrapposizione di diversi comportamenti, come la riflessione speculare e quella diffusa (fig. 2). E gli esempi potrebbero continuare.

\section{Verso una rappresentazione BIM del territorio}

Riguardo alla rappresentazione digitale inerente alla progettazione architettonica, in tempi recenti le modalità di lavoro in ambiente BIM si sono sempre più impostate come standard di settore. In un certo senso il BIM è una derivazione specializzata originata delle rappresentazioni analitiche dello spazio, le quali arrivano a comprendere non solo le caratteristiche metriche di un oggetto, ma anche numerose altre proprietà. Oltre ai dati necessari alla visualizzazione è infatti possibile associare a ciascun elemento rappresentato numerose 
informazioni, che come di prassi nell'ottica digitale, possono spaziare in ogni disciplina. Un oggetto BIM, in quanto 'contenitore', può ricondurre a tutta una serie di informazioni riguardanti la sua natura, quali ad esempio: il tipo di materiale, le caratteristiche fisiche, il costo, la provenienza, le tempistiche di assemblaggio, e così via [Hemmerling, Cocchiarella 20 I8]. Si tratta quindi di un campo di studio il cui tema di ricerca è una rappresentazione del reale sempre più comprensiva e interdisciplinare, e perciò per sua natura predisposto verso molte tematiche, divenendo terreno fertile anche per curiose sintesi di saperi [Garber 20 I4]. Una di queste potrebbe interessare la rappresentazione dell'ambiente naturale, un settore in cui le tematiche BIM hanno le potenzialità per eseguire notevoli progressi. E anzi su questo punto in particolare possono attingere a ottime esperienze nate per quel tipo di rappresentazione, più artistica e meno tecnica, che è la rappresentazione realistica del territorio. Ad esempio, un tema importante come la scelta delle essenze vegetali in un progetto non gode attualmente di strumenti BIM particolarmente efficaci, spesso limitati a semplici librerie di immagini di alberi e arbusti, dimensionate secondo valori di ingombro volumetrico di crescita massima, ed eventualmente definite nei costi.

Fig. 2. Esempio dell'utilizzo di una 'mappa' per la definizione del comportamento luminoso relativo ad una superficie. La mappa, rappresentata in basso a sinistra può essere inso a sinistra, può essere distribuzione'pseudo-statistica' del comportamento (nsunto dalla ssunto dalla luce in ogn suo punto.

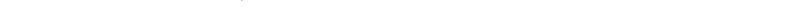

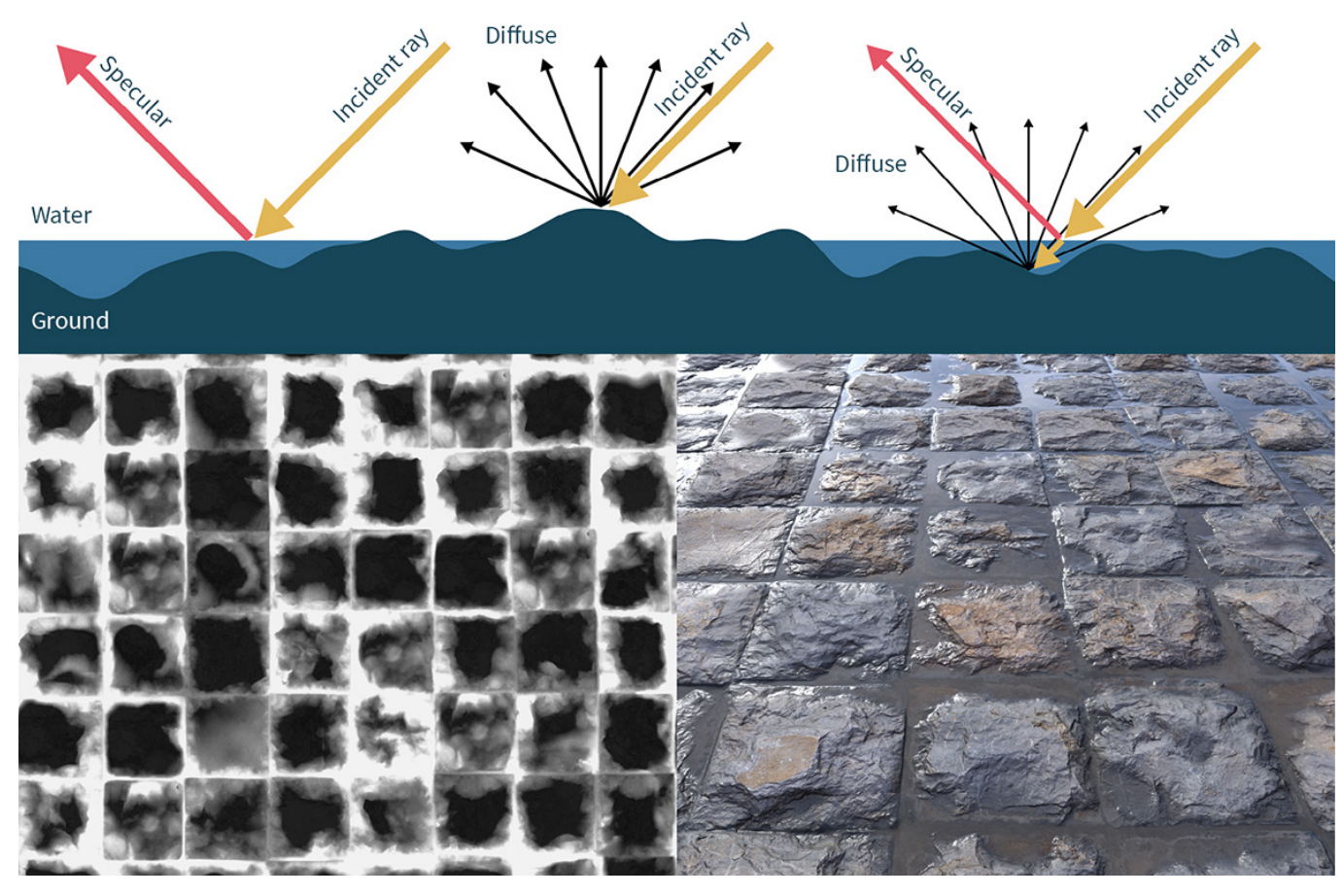

Lavorare con la vegetazione implica quindi la necessaria uscita dall'ambiente BIM, con le immaginabili conseguenze sul piano espressivo, e sul piano delle potenzialità inespresse in termini di definizione professionale di uno spazio tramite l'uso degli elementi naturali.

Ed è qui che a mio avviso la comunicazione interdisciplinare potrebbe avvalersi degli applicativi orientati all'elaborazione artistica. Molti programmi sono stati infatti sviluppati per la generazione di alberature, e altri elementi vegetali, secondo parametri formulati coerentemente con forme naturali e attendibili. Proprio come gli artisti classici erano interessati alla veridicità delle essenze da loro dipinte, anche gli artisti digitali moderni conservano il medesimo desiderio. Ovviamente le diverse possibilità offerte dalle tecnologie informatiche hanno portato a generare modelli di lavoro altamente scientifici [Reas, McWilliams, LUST 20 I0]. Gli elementi vegetali gestiti da questi applicativi possono quindi trascendere l'ambito grafico per supportare efficaci rappresentazioni metriche, a beneficio delle capacità di previsione progettuale dei professionisti coinvolti. 
Fig. 3. Alla base

dell'immagine è possibile osservare la crescita

Per diluire i possibili

errori, derivati in parte

dall'imprevedibilità della

natura, ed in parte dalle

possibili debolezze dei

software stessi, le piante

sono state racchiuse

generali. in volumi di studio più
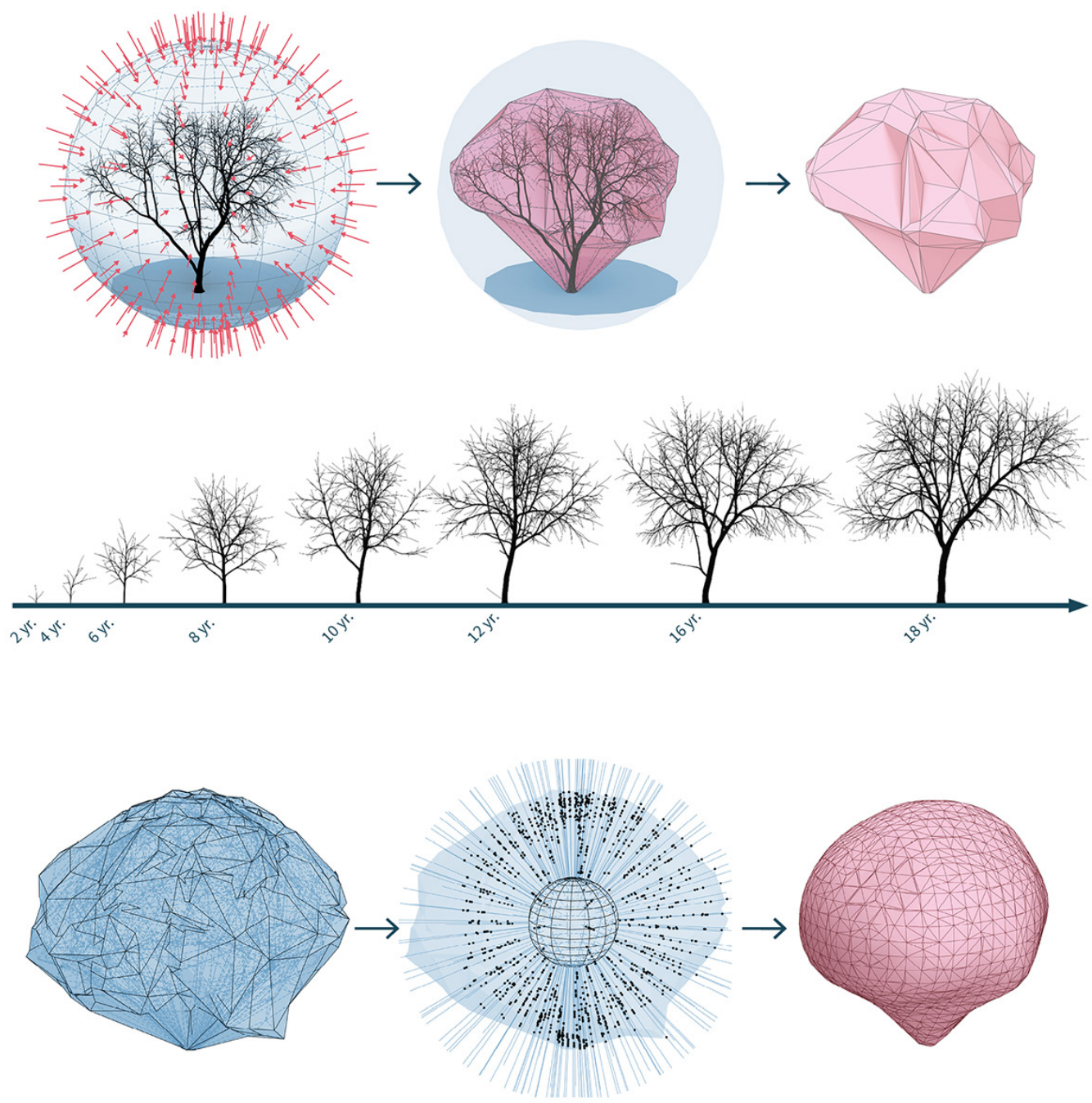

Fig. 4. Attraverso un algoritmo geometrico appositamente creato sono stati analizzati

numerosi volumi

campione. Dall'analis

effettuata è stato

generato un unic

dell'ingombro medio.

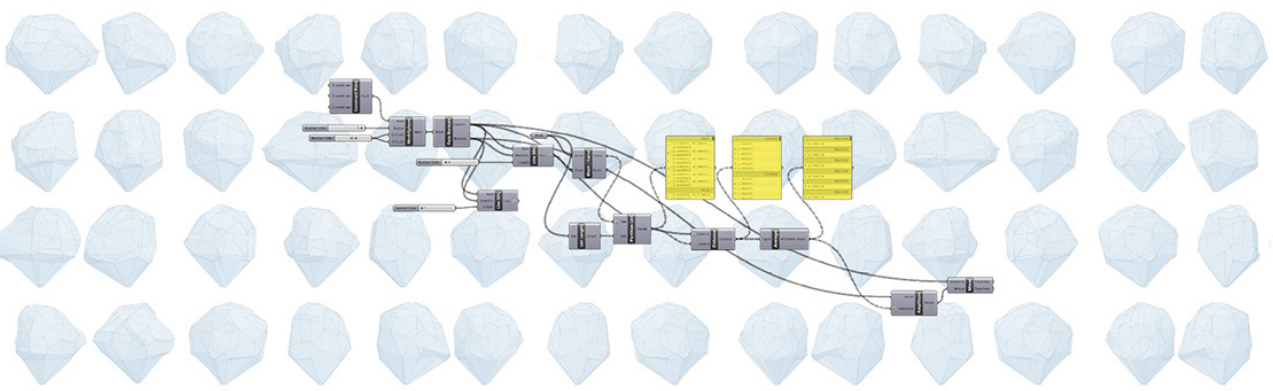


Tramite questi strumenti è possibile generare piante e crescerle virtualmente in ambienti controllati, assistendo così al loro invecchiamento.

Naturalmente non è detto che il comportamento virtuale sia identico a quello reale, ma possiamo colmare parte dell'incertezza attraverso una trattazione statistica del dato. Ad esempio, generando molteplici esemplari, anche ricorrendo a diversi programmi, creando dei veri propri campioni in grado di essere utilizzati per estrapolare informazioni non solo metriche, con minore percentuale d'errore.

Nelle figure qui presentate sono stati creati dei campioni di un tiglio di 12 anni: dalla generazione di un volume mediamente rappresentante i modelli generati è possibile determinare l'ingombro medio degli esemplari (figg. 3, 4). La possibilità di attingere a questo tipo di informazioni a mio parere può cambiare enormemente la capacità di gestire la componente naturale dei progetti. Su questi volumi possono essere svolte molteplici tipi di analisi. Può essere ad esempio calcolato il tempo medio giornaliero di illuminazione ricevuta al suolo dall'area sottostante all'essenza. Verificando così le aree più in ombra è possibile calibrare il tipo di specie erbacea più adatto rispetto all'irraggiamento dato (fig. 5). Inoltre, trasformando queste elaborazioni in mappe statistiche, è possibile popolare i territori virtuali in esame attingendo automaticamente da librerie di essenze preimpostate, imponendo che la probabilità di apparizione di una data essenza sia legata ai valori percentuali di irraggiamento. Questo tipo di studi può inoltre simulare la crescita simultanea di diverse essenze arboree, determinandone le cumulative interazioni luminose col suolo e tra loro stesse (fig. 6), consentendo di programmare, con anni di anticipo, probabili interventi di sfoltimento della vegetazione causate dall'eccessivo avvicinamento delle chiome.

Fig. 5. Attraverso degli studi luminosi condotti sul volume di sintesi possono venire create mappature delle essenze erbacee direttamente relazionate alla quantità ombra al suolo garantita dalla pianta analizzata.

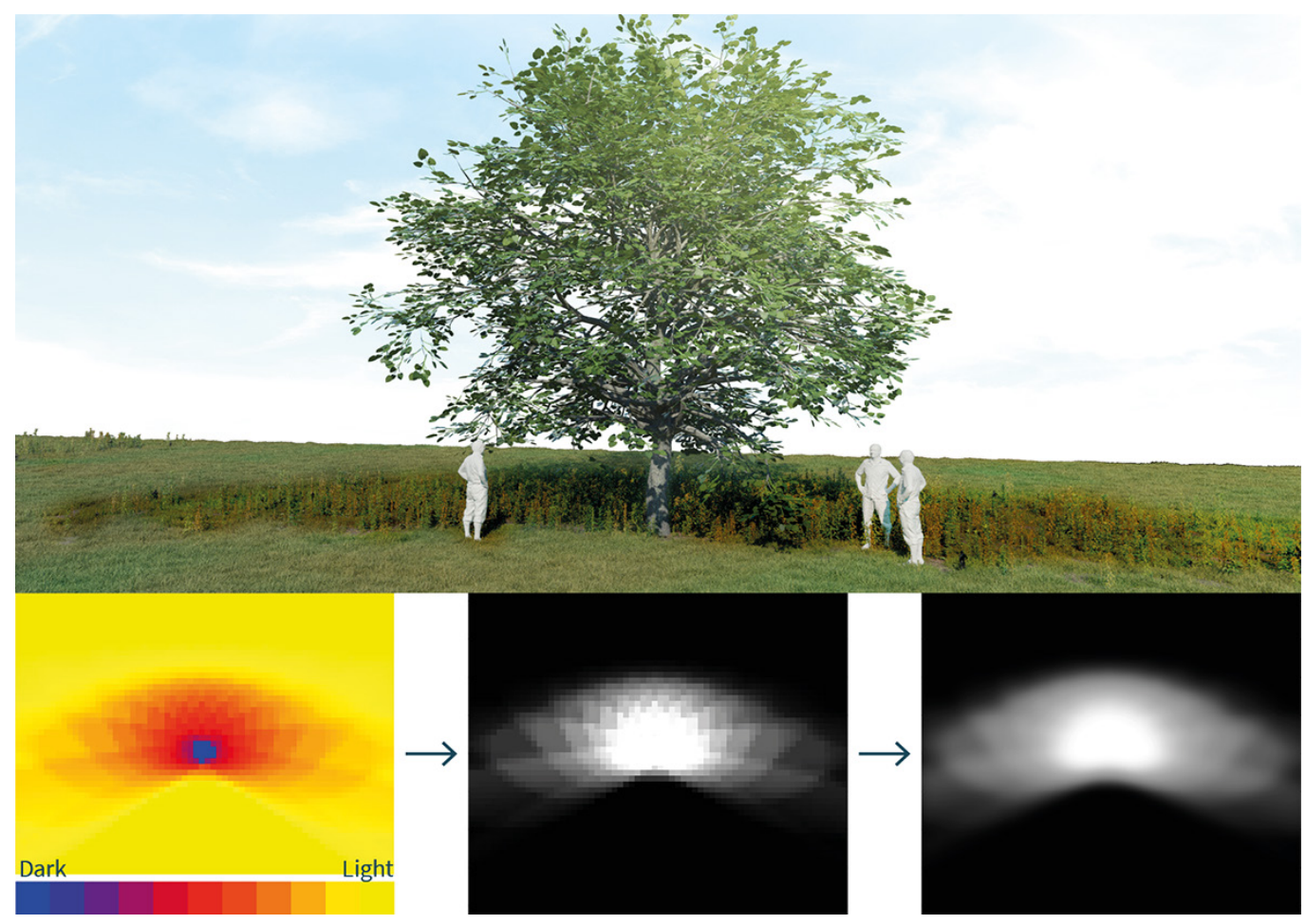

Grazie all'interpretazione statistica generale, delle istanze puntuali generate da questi strumenti artistici, i metodi di rappresentazione BIM potrebbero quindi un giorno incorporare numerosi dati per la progettazione del verde: l'età delle essenze, le previsioni di crescita e di intervento, il loro ombreggiamento e le dimensioni possibili, attualizzate in diversi periodi temporali. 


\section{Applicazione delle metodologie, un caso studio}

Questi studi sono in parte derivati dalla relazione della mia tesi di laurea magistrale [Cavaglià, Cocchiarella 20 19] riguardante un'ipotesi di adeguamento della fruizione territoriale del comune di Portovenere, in Liguria (Italia).

Il borgo storico di Portovenere è un sito di interesse storico e naturalistico molto importante, e in particolare è oggi considerato un luogo turistico di grande pregio. Una serie di ostacoli posti sul territorio rende però difficile la frequentazione dei luoghi esterni al borgo, una svantaggiosa condizione che, a mio avviso, può essere superata con l'implementazione di migliori collegamenti fisici e visuali.

Lo studio si è quindi soffermato sulla identificazione delle aree di maggior interesse, dei punti più significativi di fruizione visiva, e dell'ottimizzazione dei sentieri, con l'ausilio del calcolo parametrico in ambiente 3D.

Lungo uno dei sentieri di collegamento progettati per questo fine fu inoltre prevista un'area di sosta nel verde.

Allinterno dell'area alcune strutture lignee ne avrebbero diviso lo spazio, divenendo altresì curiosi mezzi per osservare importanti landmark identificati sul territorio, grazie alla loro configurazione simile a periscopi, con annessi dispositivi di cattura e riproduzione acustica dei suoni naturali. Ciò avrebbe possibilmente incoraggiato i visitatori a includere questi landmark come meta di visita (figg. 7, 8).

La progettazione di quest'area verde si è avvalsa non solo di un clone tridimensionale dell'intero territorio del comune, in modo da calibrare nel modo corretto l'inclinazione delle strutture periscopiche per catturare adeguatamente i soggetti scelti (fig. 9). Ma la presenza di queste strutture così alte ha anche necessitato di una progettazione del verde attenta a non mettere a rischio la stabilità delle strutture stesse, scegliendo essenze con una crescita compatibile all'ecosistema locale, e allo stesso modo in grado di comporre uno spazio dalle qualità estetiche gradevoli per la sosta turistica (figg. 10, I I).

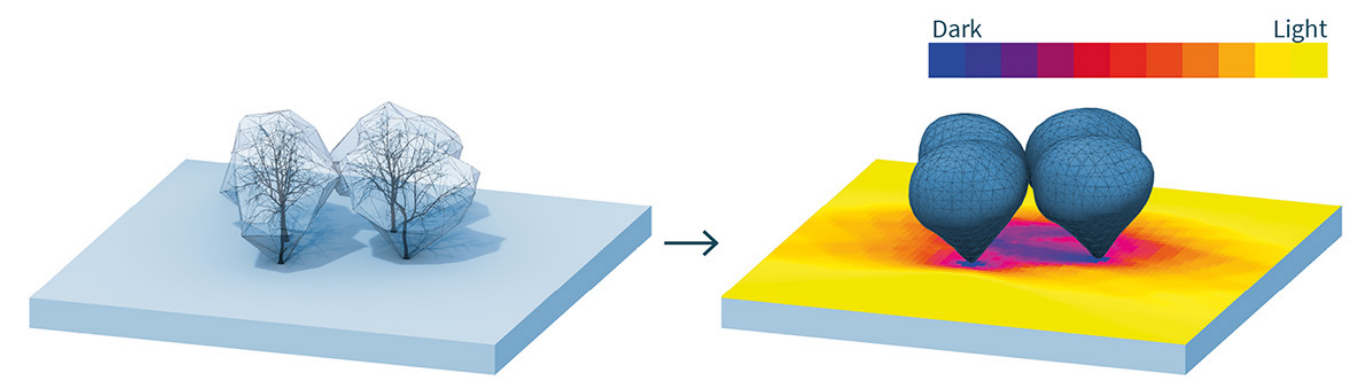

\section{Conclusioni}

Le potenzialità dei sistemi informatici di connettere dati apparentemente non relazionabili è uno dei più grandi pregi di questi moderni mezzi. Agli operatori è naturalmente richiesta attenzione e competenza nel loro utilizzo, eppure una qualità altrettanto necessaria è la fantasia, la creatività di piegarli secondo le specifiche necessità.

Strumenti apparentemente rigidi come quelli inerenti alla progettazione BIM, possono così avvantaggiarsi di un approccio creativo capace di incanalare esperienze maturate in vari campi operativi. La sfera di interesse artistico ha in questo senso molto da offrire oltre alla semplice realizzazione di immagini esteticamente gradevoli, ed anzi può costituire una preziosa risorsa così come già per molto tempo in passato. 
Fig. 7.Vista dall'alto di

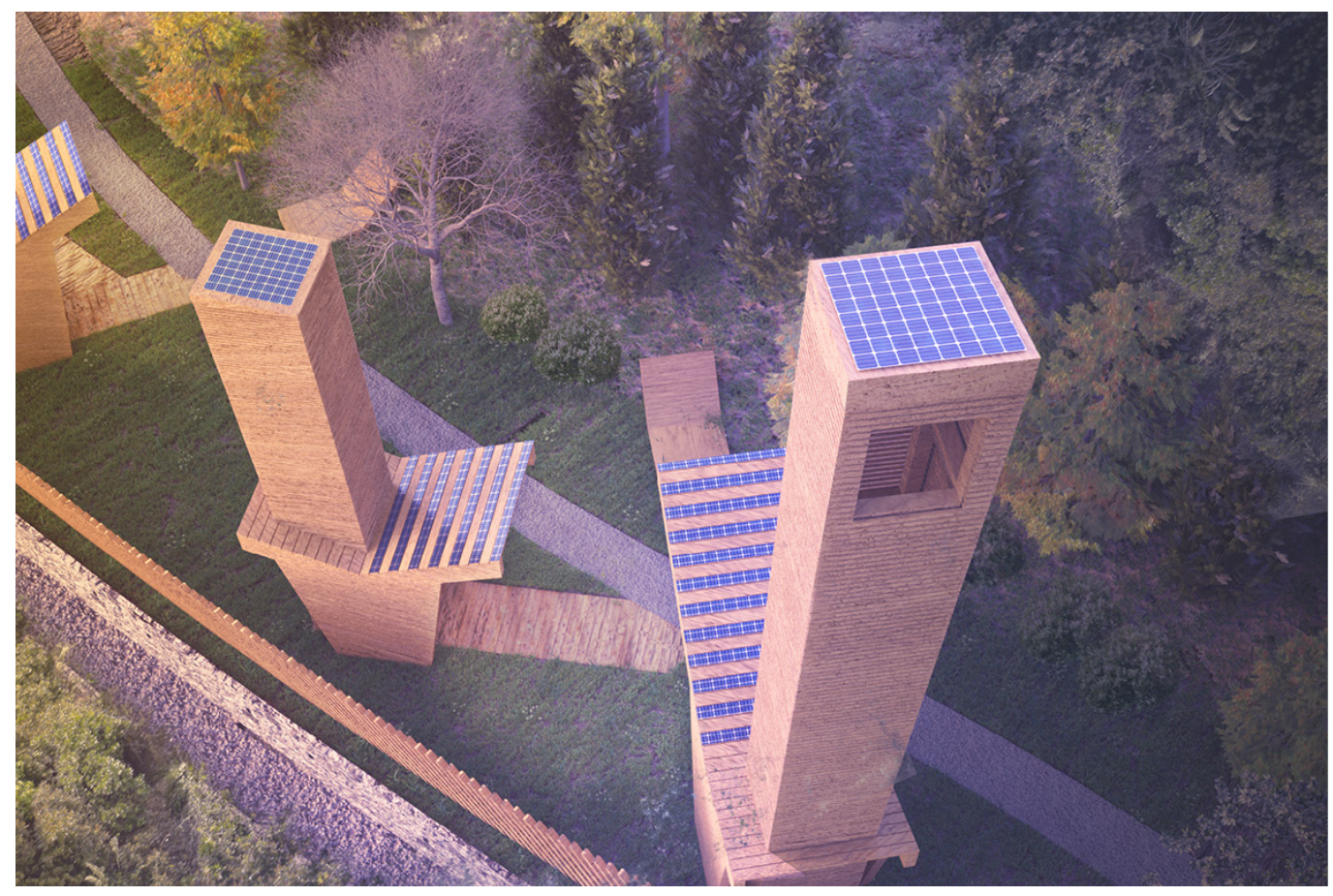

Fig. 8.Vista dell'area

di sosta, e dettaglio
dell'attacco a terra delle

strutture di osservazione

del territorio.

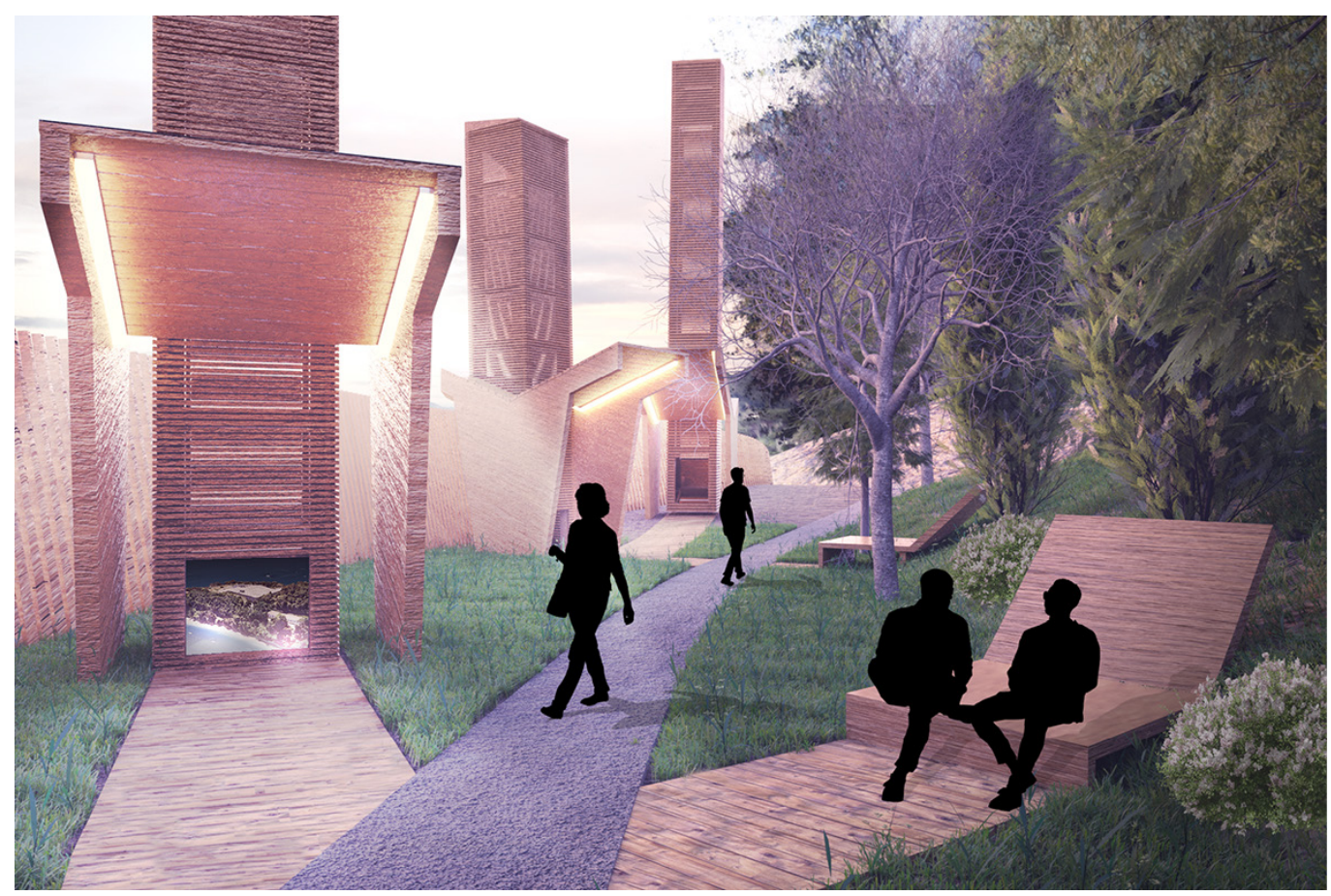


Fig. 9. Studio del collocamento delle strutture mediante la calibrazione delle stesse per catturare determinat punti del territorio.
Fig. 10. Sezione

trutture Mentre il periscopio

interno fornisce un

collegamento visivo ai soggetti, del sistemi di riproduzione audio rendono udibili i suon catturati da dei microfoni collocati in prossimità dei punti inquadrati. Ciò permette di riproporre sia la presenza visiva, che uditiva, dei luoghi.

Fig. I I. Mappa generata da un algoritmo parametrico di essenze erbacee a terra modo consono rispetto alle dimensioni di crescita. Seppur questa indicazione di massima possa essere di molto approfondita

è comunque utile per

prendere alcune iniziali

decisioni riguardo la

progettazione della

componente naturale di questo spazio.
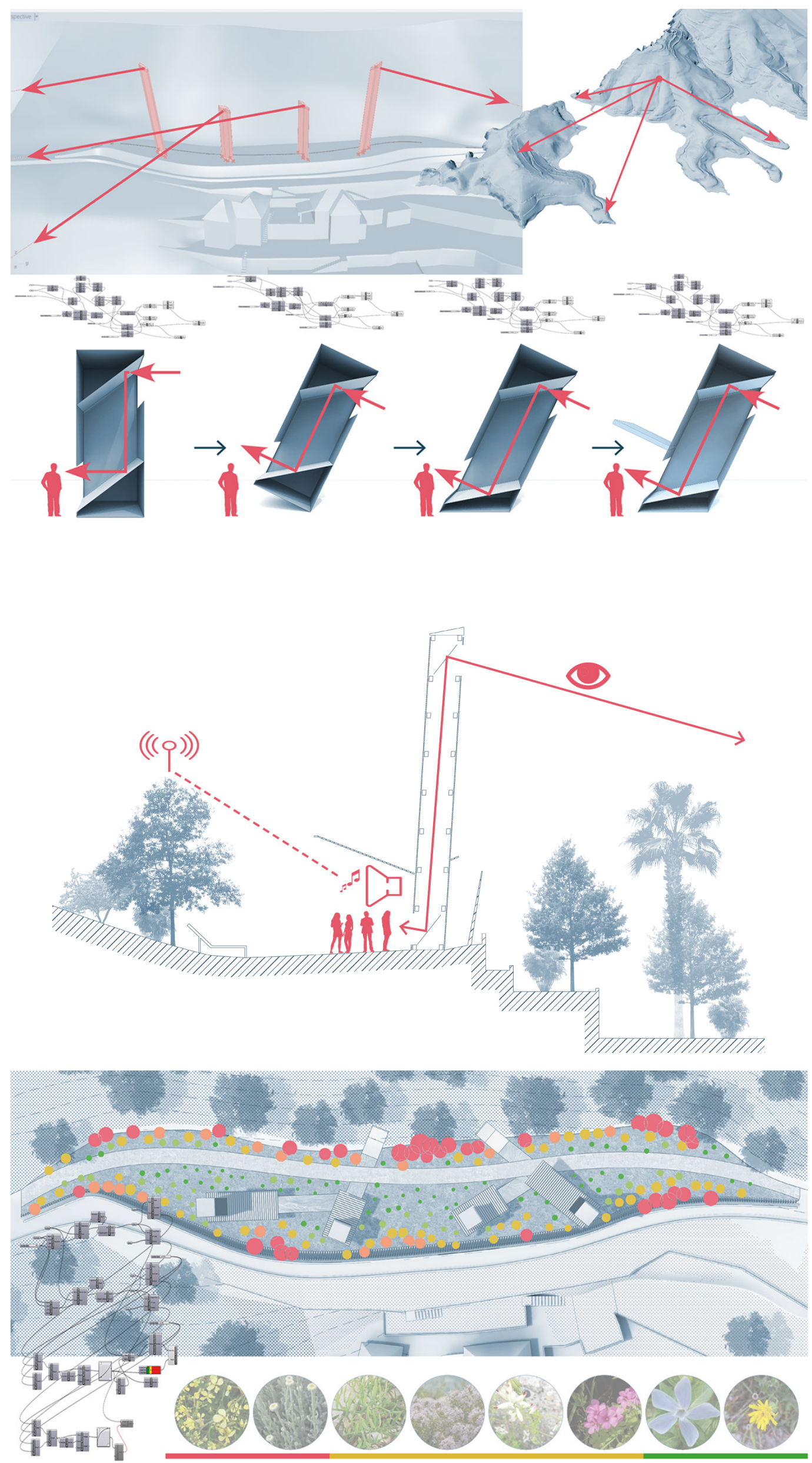


\section{Riferimenti bibliografici}

Cavaglià Matteo, Cocchiarella Luigi (2019). Pipe(line) dreaming. Rappresentazioni, strumenti, tecniche e processi fra indagine e progetto nel territorio di Portovenere. Milano: Politecnico di Milano. <http://hdl.handle.net/l0589/|48286>.

Casey Reas, Chandler McWilliams, LUST (20 I 0). Form + Code in Design, Art and Architecture. New York: Princeton Architectural Press.

Garber Richard (20I4). BIM DESIGN, realising the creative potential of building information modelling. Chichester: John Wiley \& Sons Ltd.

Hemmerling Marco, Cocchiarella Luigi (a cura di). (2018). Informed architecture Computational Strategies in Architectural Design. Cologne: Springer.

McDermott (2018). The PBR guide, a handbook for physically based rendering. 深圳: Allegorithmic SAS.

Vulpiani Angelo (2018). Caso, probabilità e complessità. Roma: Ediesse.

Autore

Matteo Cavaglià, Politecnico di Milano, cavaglia.matteo.main@gmail.com

Per citare questo capitolo: Cavaglià Matteo (2020). Imparare dalla rappresentazione digitale del paesaggio, tra suggestioni 'romantiche' e rigore matematico/Learning from the digital representation of the landscape, between 'romantic' suggestion and mathematical rigor. In Arena A., Arena M., Brandolino R.G., Colistra D., Ginex G., Mediati D., Nucifora S., Raffa P. (a cura di). Connettere. Un disegno per annodare e tessere. Atti del $42^{\circ}$ Convegno Internazionale dei Docenti delle Discipline della Rappresentazione/Connecting. Drawing for weaving relationships. Proceedings of the 42th International Conference of Representation Disciplines Teachers. Milano: FrancoAngeli, pp. 276-295. 


\title{
Learning from the Digital Representation of the Landscape, between 'Romantic' Suggestions and Mathematical Rigor
}

\author{
Matteo Cavaglià
}

\section{Abstract}

One of the greatest potentials of the modern digital tools of representation is the possibility to reach a strong connection between different disciplines.

Thanks to this fact, the digital representation of the territory can draw from experiences gained from other fields of investigation, expanding its possibilities to compile more refined models of the physical reality represented.

In this context, BIM tools are one of the most interesting methodologies currently available. This type of tool exploits the characteristic of storing more information than what is needed to achieve simple visualization; transforming each object represented into a digital container for an infinite list of spatial data, material data, economic data, time-related info, and so on. But I think that BIM tools still possess room for improvement when dealing with the natural environment. About this matter, a valid aid for interfacing with this typology of territorial studies can come from the field of traditional artistic representation of the landscape, also by treating it by the use of digital systems.

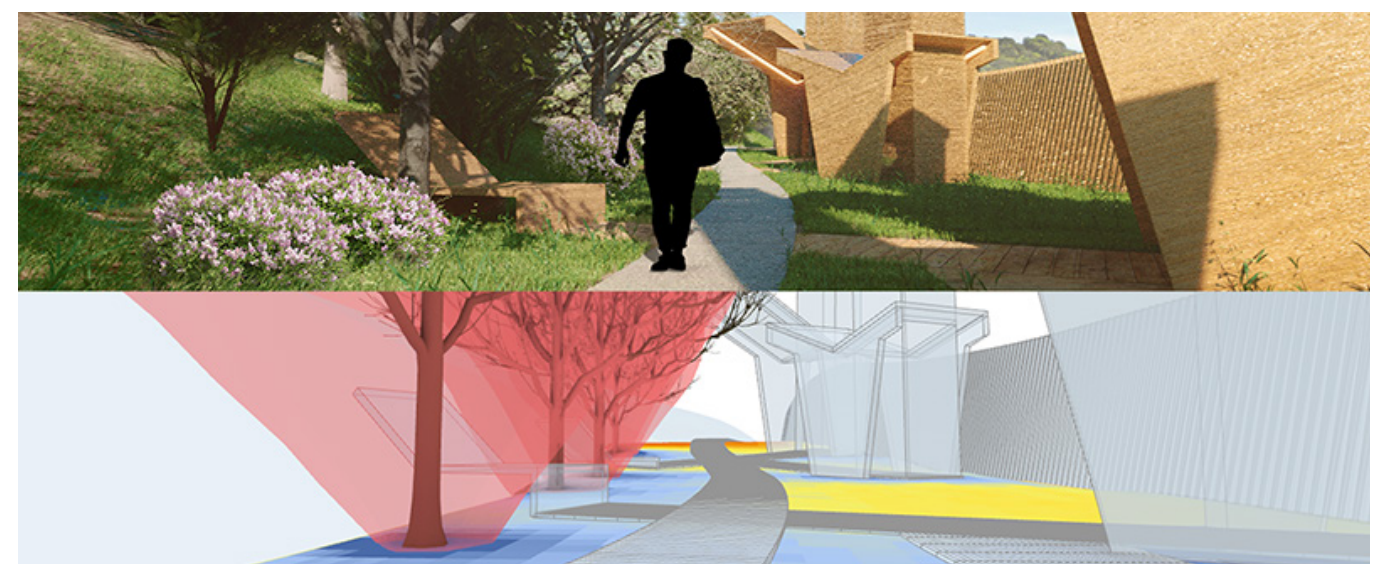


The data exchange between reality and virtual environment in the representation process I think that digital graphics, particularly realistic representation, can be a very charming subject, especially on the young generations approaching the world of representation. Although there is a bitter feeling about the fact that deepening these themes may sometimes lead to neglect the analog component of the design, I believe that these two methodologies are not in conflict, but rather fuel themselves from the same desire for knowledge of the world and its parts.

This fact is even more real when speaking about the representation of the territory. If we overlook the obvious difference between the digital and analog approach, it's possible to say that there isn't a substantial gap in the way the two deal, and confront themselves, with reality. Like the artists of the past sometimes used their work as a lab for testing geometrical, mathematical and naturalistic theories, reaching in this way the interdisciplinary connection necessary to seek new knowledge, the present users of digital media can also perform similarly.

Instinctively, this line of work can seem far from the type of environment found in the rigid definition of the software-based workflow. Where the initial relationship with these tools may seem very stiff, given that although effective in its area of competence, each software is at first sight unable to satisfy requests, just slightly different, from the specific ones for which it was designed. This limit is actually an illusion, as the most exceptional capacity of IT systems is the ability to allow the communication between different types of documents and disciplinary areas. Although every digital information is shown to us in the way we expect it to be: for example, a sound will be reproduced as a sound, and an image as an image; for a computer system, all data are equally encoded in the form of sequences of binary values. What differentiates the type of presentation is the 'vocabulary' used to read them, therefore by changing the 'cipher' it is possible to see the data in another form.

Fundamentally, for example, a sound can be displayed as an image, or an image can be played as a sound. Such transformations also allow communication between different software, and therefore, between different fields of research, filling what one instrument may lack through the support of another. The use of it means is therefore not to be considered a 'solo', but rather an 'orchestra', in which different tools interact by drawing from the same score, in this case from the digital data.

The digital representation of the territory can also be enriched with this possibility, drawing synergistically from experiences gained in many areas of investigation, thus generating much more than the simple visualization of a landscape, although the final result may recall that type of experience.

My background as an architect has molded my relationship with these issues in a way centered around their use for design. But when dealing with the study of the territory, however, I still believe that the architect's sensibility can positively contaminate itself, assimilating an artistic meaning, albeit in a different way from other professions.

\section{The 'materiality' of digital representation}

I believe that the digital representation of a landscape operates through two types of channels, each focused specifically on an aspect of the real space.

The first one deals with the metric dimension of space. We could define it as an analytical representation that does not seek graphic realism but instead, dimensional and geometrical correctness. This is precisely the type of territorial representation useful in particular to architects and engineers for simulating the influence of their projects on reality.

On the other hand, the second one pursues the path of the greatest possible realism, reconstructing three-dimensionally not only the geometry but also the materiality of a territory, that is, the relationship of the objects with their perceptual impact, focusing on colors and the behavior of light (fig. I).

This is precisely the type of realistic representation that often attracts the greatest interest, and that also possesses the largest array of contact points with other disciplines. Realistically 
Fig. I.This picture shows a comparison of the sample made in the form f an analyticat metric modelandareatic model. representing the territory, including the non-visible aspects of it, is indeed a theme that calls into question a series of topics as extensive as reality itself.These circumstances, considered in light of the innate ability of the it environment to connect different areas, can lead the user towards unusual approaches. In this regard, one of the concepts transmitted unconsciously through the experience of these tools concerns the use of statistics to support the naturalistic modeling of representation. In my opinion, the statistic is a wonderful key for understanding and exploiting many aspects of reality. It is not for nothing that science affirms that, in a certain sense, that is the foundation of reality itself [Vulpiani 20 I8]. The use of statistical, or pseudo-statistical, systems in a realistic digital representation is an acquired
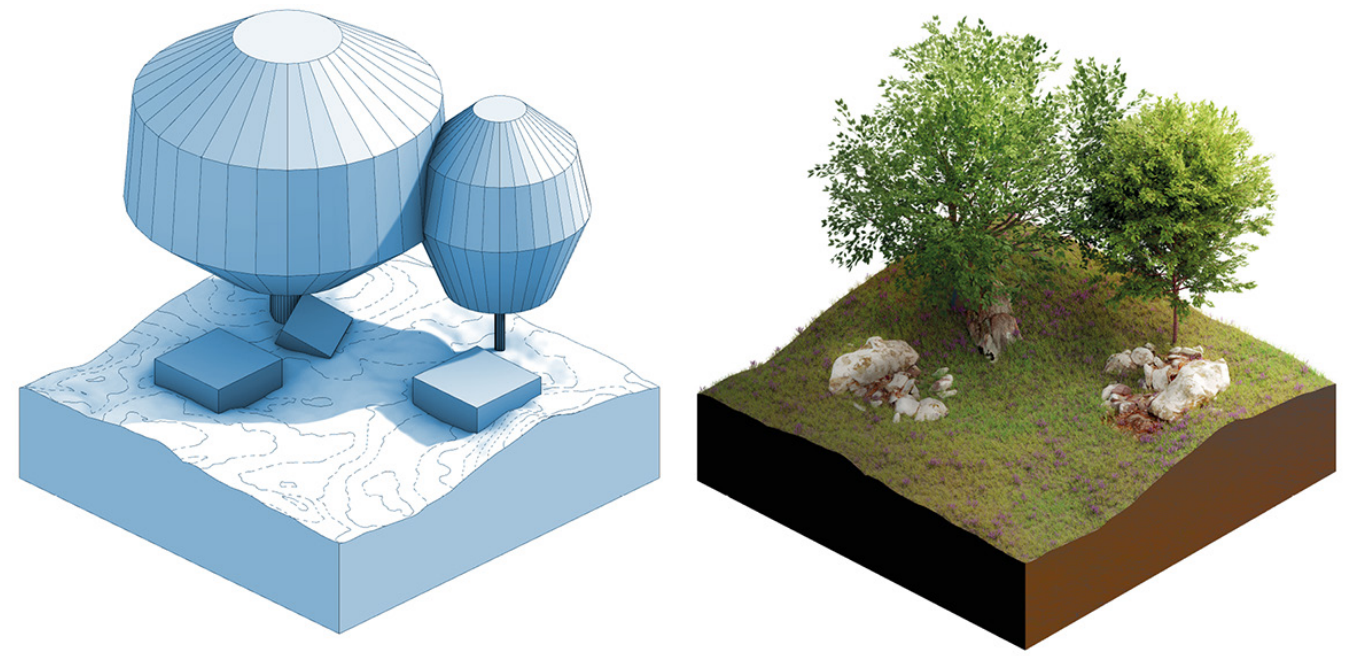

fact. One of the prevailing ways in which they are exploited is through the use of gray-scale images called "maps". Just like real maps, these images have information depicted on their surface, which in this case can be read in probabilistic terms. Each pixel of the map encodes the state of the area onto which it will be projected, in a way that if the pixel is black an associated phenomenon will have a $0 \%$ probability of occurring, on the contrary, if the pixel is white it will occur with a probability of $100 \%$. Lastly, the intermediate values will overlap the events based on the specific percentage value [McDermott 20 I8].

Maps find application, for example, in the coding of light reflection by synthesizing the overlapping behaviors of different types of reflection, such as specular and diffuse reflection (fig. 2). And the examples could continue.

\section{Towards a BIM representation of the territory}

Concerning the digital representation specific to architectural design, in recent times the working methods typical of the BIM environment have progressively become the industry standard. In a sense, BIM is a specialization of the analytical representations of space, which focus not only on the metrical characteristics of an object but also on numerous other properties. In addition to the data necessary for visualization, it is possible to link a large amount of information to each element. A BIM object act essentially as a "container" that can lead to a whole series of information regarding its nature, such as the type of material, the physical characteristics, the cost, the origin, the assembly timing, and so on [Hemmerling, Cocchiarella 2018].

BIM is a field of study whose research topic is an increasingly comprehensive and interdisciplinary representation of reality, and therefore it is predisposed towards many issues, becoming fertile ground also for curious syntheses of knowledge [Garber 20I4]. 
One of these syntheses could concern the representation of the natural environment, a matter about which BIM has the potential to make significant progress. Also, on this point, it could prove beneficial drawing from excellent experiences born from that type of representation, more artistic and less technical, that is the realistic representation of the territory. For example, an important theme such as the choice of plant species for a project does not currently benefit from particularly effective BIM tools. The choice is often limited to simple image libraries of trees and shrubs, sized according to average maximum growth dimensions, and possibly defined in costs.

Because of this, working with vegetation implies the necessity to exit from the BIM environment, with imaginable consequences on the expressive level, and risking to underestimate the potential of defining space through the use of natural elements.

In this context interdisciplinary communication could make use of applications oriented to artistic processing. Until now many programs have been developed for the generation of trees, and other plant elements, according to natural-like parameters and reliable forms. Just as classical artists were interested in the reliability of the essences they painted, modern

Fig. 2. This picture describes an example of the use of a "map" to define the behavior of light reflection on a surface. The map represented at the bottom left corner can be interpreted as a "pseu"do-statistical" distribution ofthe different behion ossumed by light at each assumed by light at each point

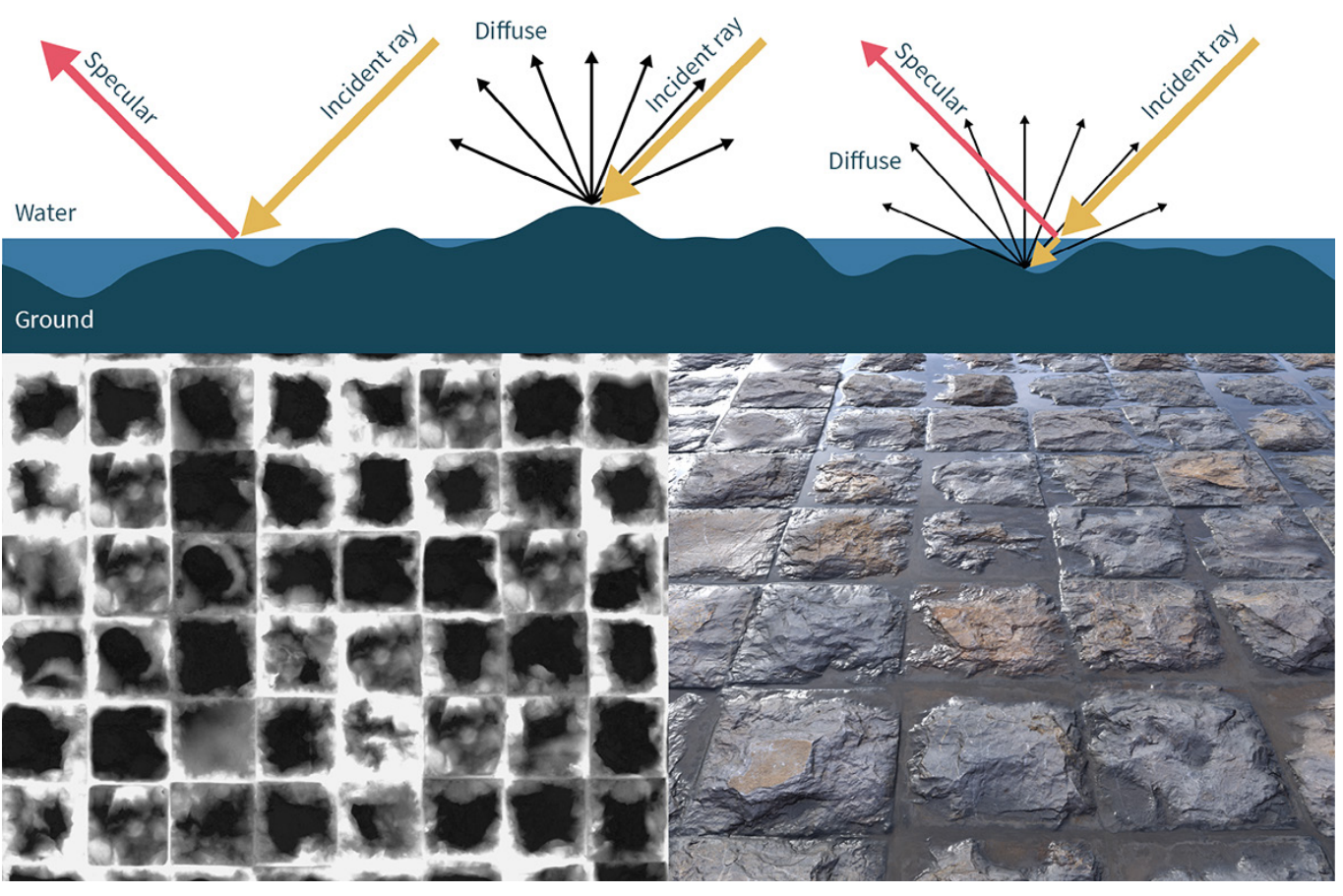

digital artists also retain the same desire. But, the various possibilities offered by information technologies have led to the generation of highly scientific growth models [Reas, McWilliams, LUST 20I0]. The plant elements managed by these applications can, therefore, transcend the graphic context to support effective metric representations, benefitting the design foreseeing skills of the professionals involved.

Through these tools it is possible to generate plants and grow them in virtual controlled environments, looking at their aging process.

Of course, it is not certain that the virtual behavior will match with the real one, but we can exclude part of the uncertainty through a statistical treatment of the data. For example, by generating multiple specimens, or by resorting to different programs, and treating the results as samples to be used to extrapolate metrical information, and more, lowering in this way the margin of error.

In the figures presented here, samples of a 12-year-old linden have been created and sim- 
Fig. 3. At the bottom of the image, it's possible to see the virtual growth of a tree. To thin dow the possible errors,

partly derived from

the unpredictability of the possib weakness the possibleweaknesses of the software itself the plants have been enclosed by more
volumes to study.

Fig. 4. A geometric algorithm was scripted to take numerous sample volumes and summarize them in a single shape representing the average size of the whole group.
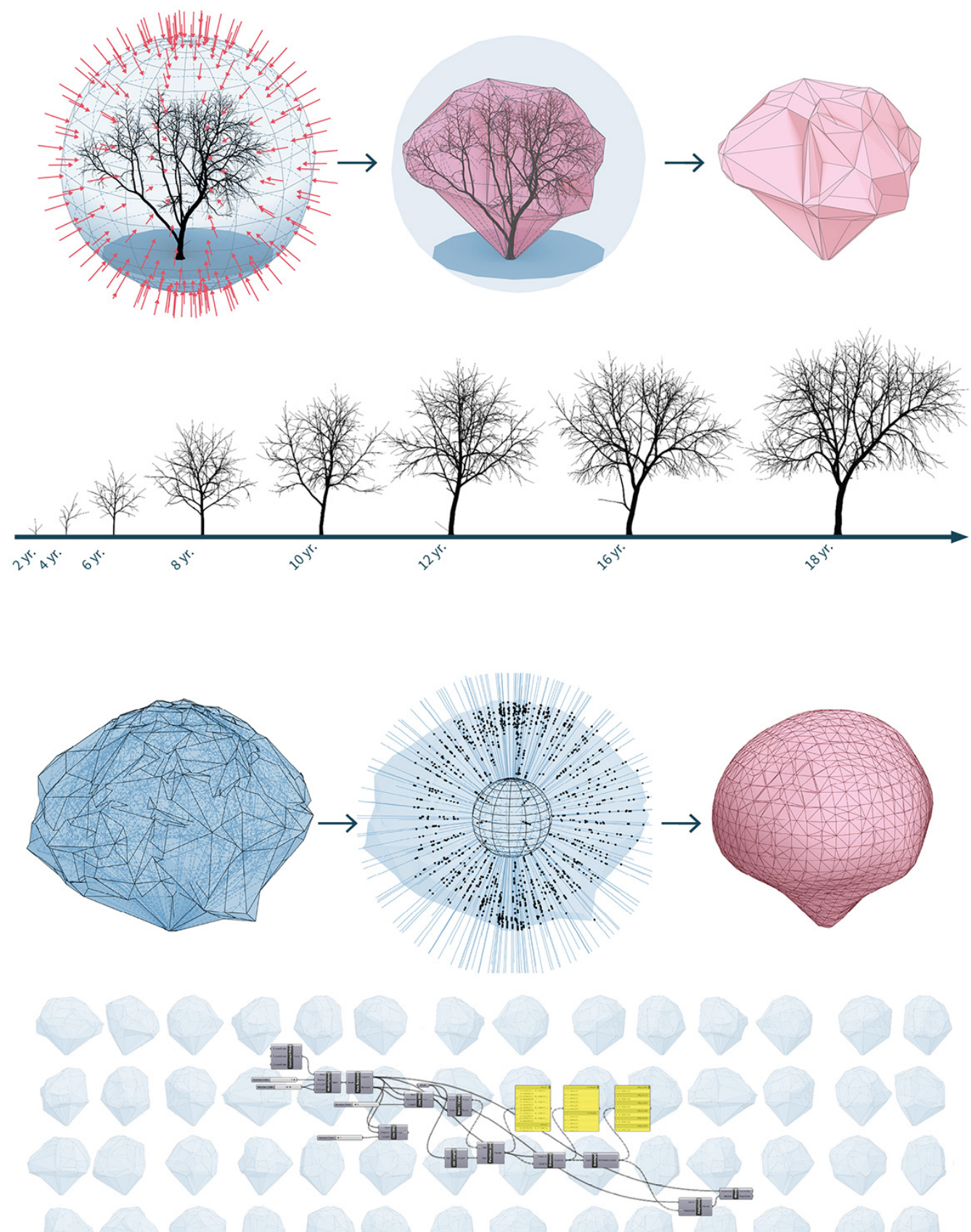
plified into average volumes. From there it is possible to determine the average size of the specimens (figs. 3, 4). The possibility to draw from this type of information can greatly change the ability to manage the natural component of projects. Multiple types of analysis can be carried out on these volumes. For example, the average daily lighting time received on the ground from the area below the tree can be calculated. By checking the shaded areas, it is possible to calibrate the most suitable type of herbaceous species with respect to the given radiation (fig. 5). Furthermore, by transforming these elaborations into statistical maps, it is possible to populate the virtual territories in question by automatically drawing from libraries of preset species, imposing that the probability of appearance of a given plant is linked to the percentage values of irradiation.

This type of study can also simulate the simultaneous growth of different tree species, determining their cumulative luminous interactions with the soil and between themselves (fig. 6), allowing the planning, with years in advance, of possible operations of pruning the vegetation caused by the excessive approach of the crowns.

Thanks to the general statistical interpretation of the specific requests generated by these artistic tools, the BIM representation methods could, therefore, one day incorporate numerous data for the design of the green: the age of the species, the growth and intervention forecasts, their shading and possible dimensions, updated in different time periods.

Fig. 5. Light studies conducted on the previously created shape can be used as a base for defining a map of the herbaceous species directly related to the amount of shade on the ground cast by the analyzed plant.

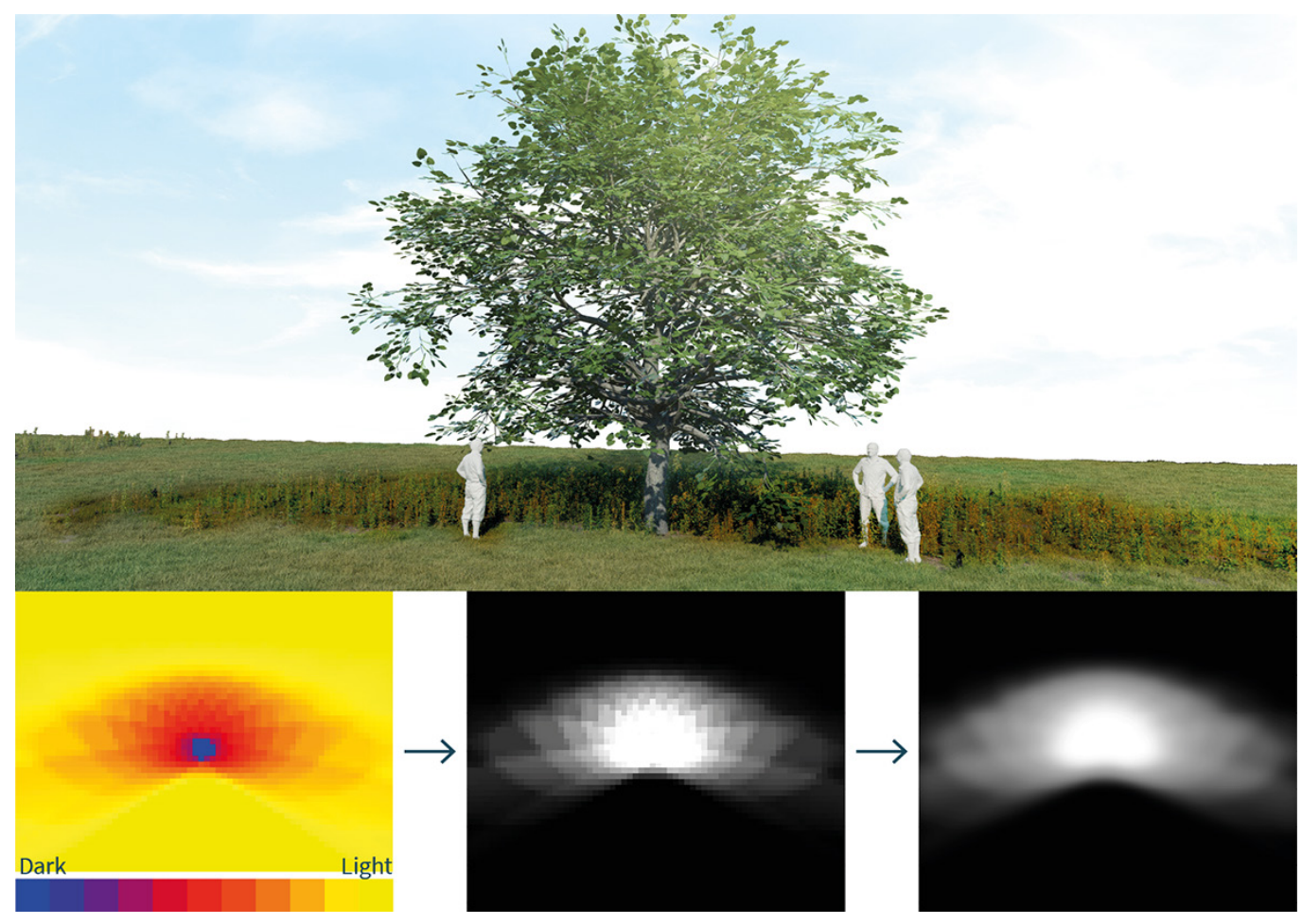

\section{Application of methodologies, a case study}

These studies are partly derived from the report of my master's degree thesis [Cavaglià, Cocchiarella 2019] concerning a hypothesis of improvement about the territorial accessibility of the environment of the municipality of Portovenere, in Liguria (Italy).

The historic town of Portovenere is the site of very important historical and naturalistic areas and is now considered a touristic site of great value. A series of obstacles placed on 
the territory, however, make it difficult for the tourist to easily access places outside the Old-Town, a disadvantageous condition which, in my opinion, could be overcome with the implementation of better physical and visual connections.

The study then focused on the identification of the areas of greatest interest, the most significant points of visual enjoyment, and the optimization of the paths connecting them, with the aid of parametric calculation in a 3D environment.

Along one of the main paths designed for this purpose, a rest area in the greenery was also provided.

Within this area, some wooden structures would have divided the space, becoming curious means of observing important landmarks identified in the area, thanks to their configuration similar to periscopes, with attached devices for capturing and reproducing natural sounds. This would have possibly encouraged visitors to include these landmarks as a visiting destination (figs. 7, 8).

The design of this green area made use not only of a three-dimensional clone of the entire territory of the municipality, in order to correctly calibrate the inclination of the periscopic structures to adequately capture the chosen subjects (fig. 9). But the height of these structures, also required a green design careful not to negatively interact with them, choosing species with a growth compatible with the local ecosystem, and in the same way capable of composing space with pleasant aesthetic qualities for the tourist stop (figs. I0, I I).

\section{Conclusions}

The potential of computer systems to connect apparently unrelated data is one of the greatest advantages of these modern means. The users are naturally required to pay attention and be experts in their use, yet an equally necessary quality is having the imagination, the creativity of bending them according to the specific need at hand. Apparently, rigid tools

Fig. 6. The same analysis procedure can also be repeated simultaneously on groups of plants, and not only single specimens.

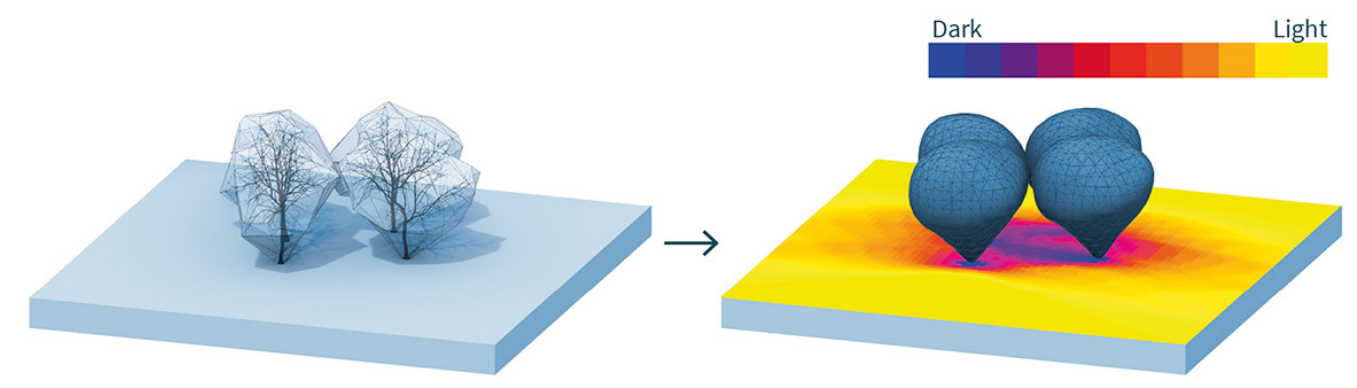

such as BIM tools can also take advantage of a creative approach capable of channeling experiences gained in various operational fields. The sphere of artistic interest, in this direction, has a lot to offer in addition to the creation of aesthetically pleasing images, and indeed can be a precious resource, just as it has already been for a long time in the past. 
Fig. 7. Top view of part of the resting area.

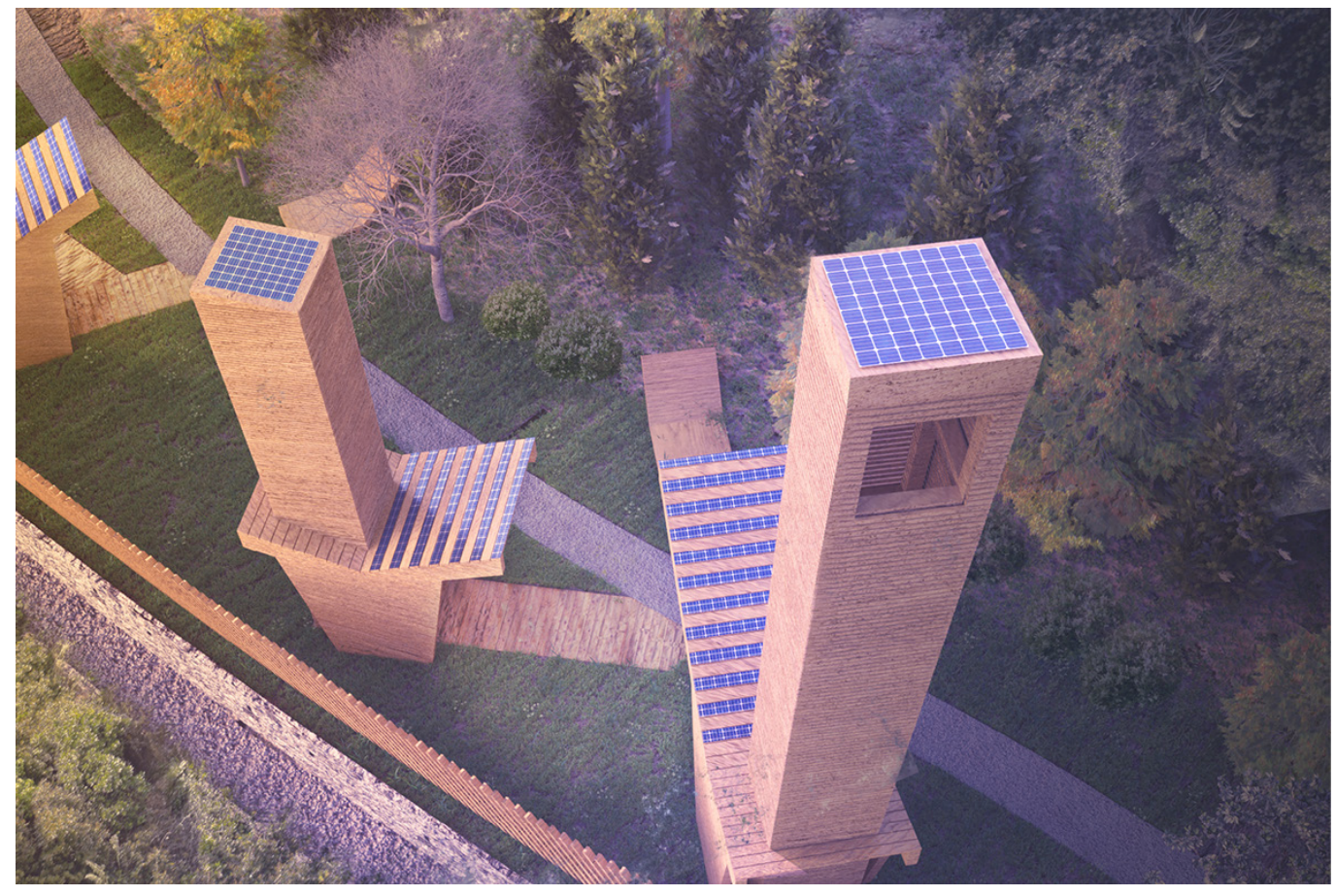

Fig. 8.View of the resting area, and detail of the link on the ground of the observation structures of the territory.

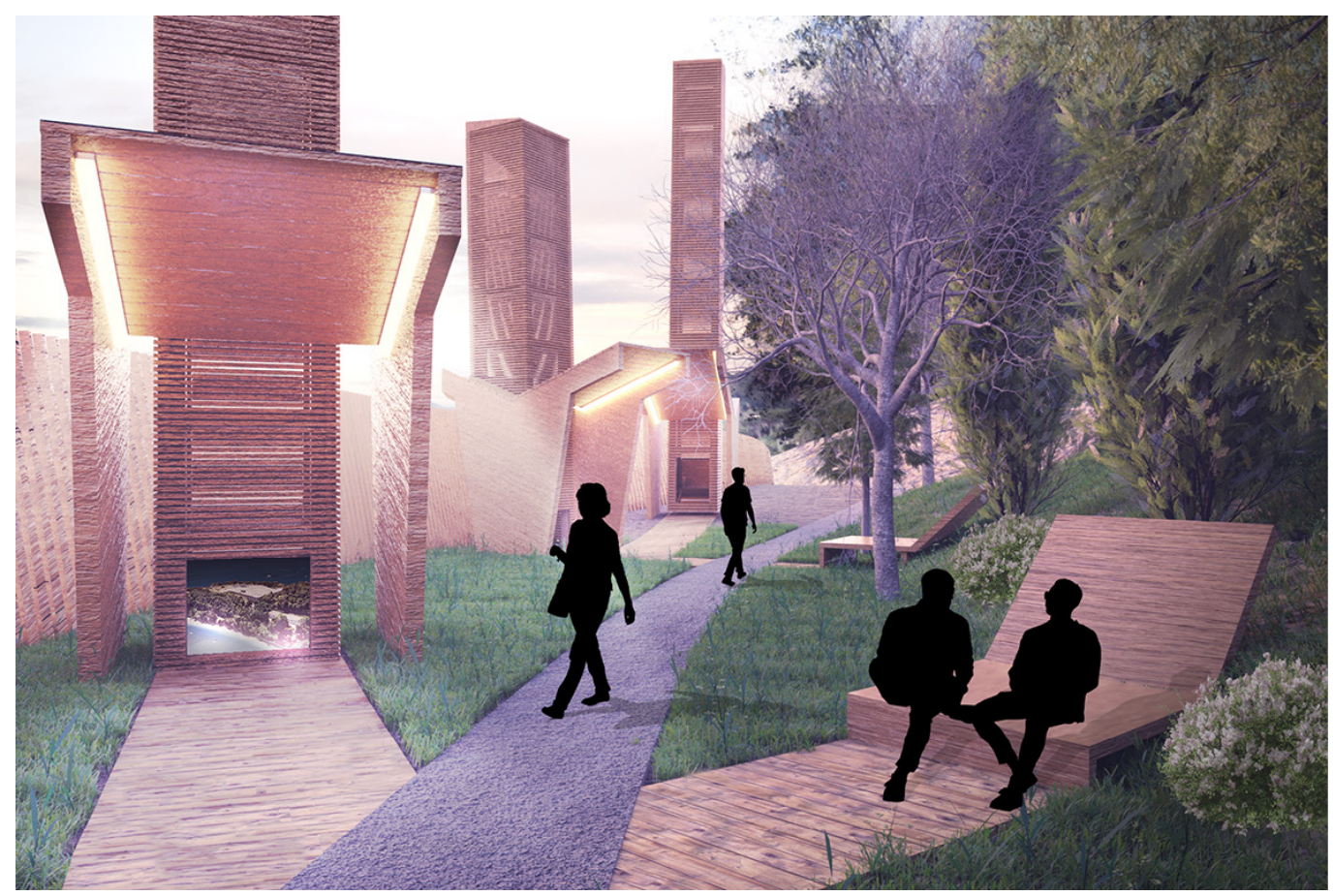


Fig. 9. Study of the placement of the structures, by calibrating points of the territory.

Fig. 10. Schematic section of the structures. While the internal periscope provides a visual connection to the chosen landmarks, audio reproduction systems play the sounds captured by microphones placed near the same points. This allows us to deliver both the visual and auditory presence of places.

Fig. I I. Map generated by a parametric algorithm for placing herbaceous species on the ground in a way that is appropriate to their growth. Although this general indication can be greatly expanded, it is still useful for making some initial decisions

regarding the design of the natural component of this space.
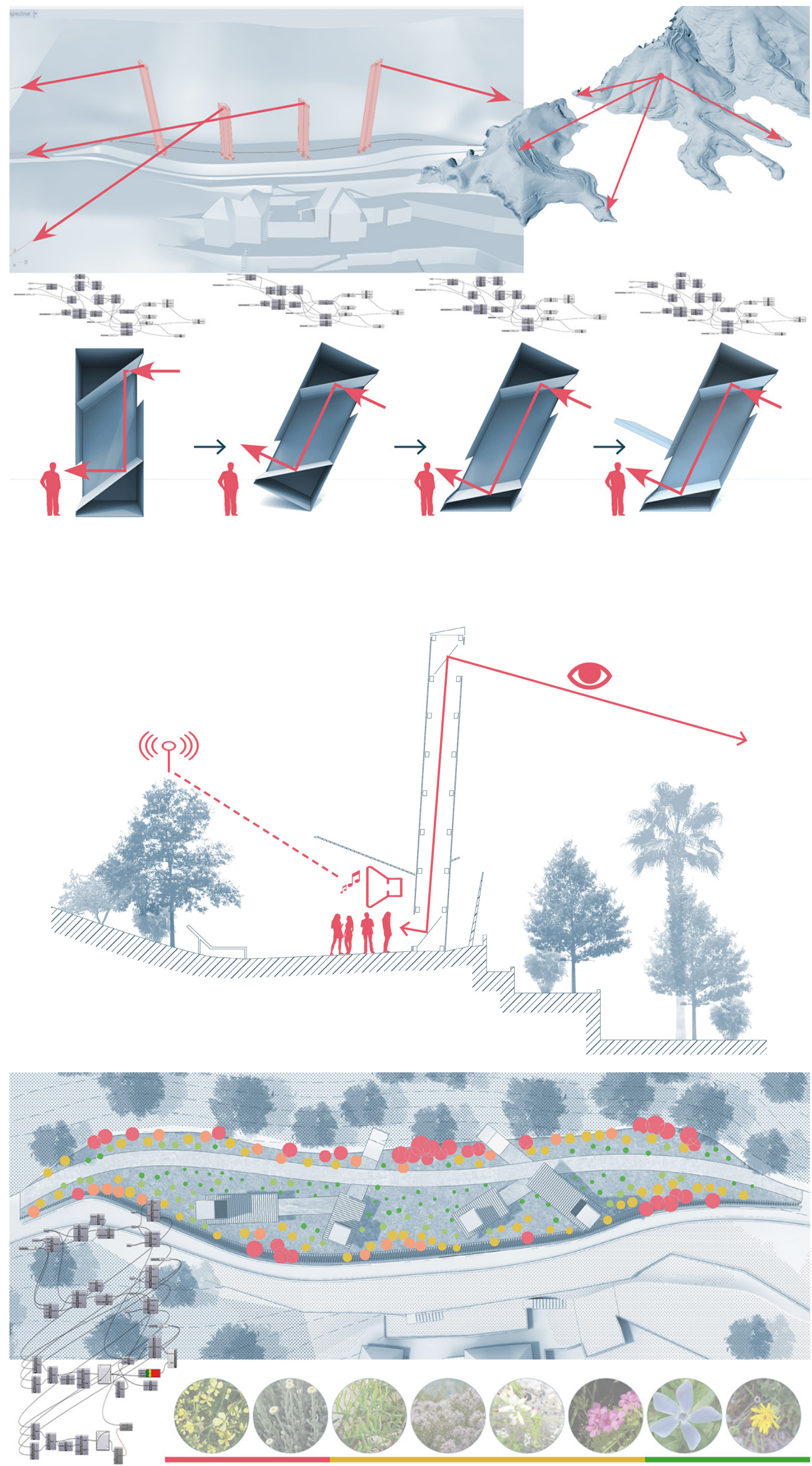


\section{References}

Cavaglià Matteo, Cocchiarella Luigi (2019). Pipe(line) dreaming. Rappresentazioni, strumenti, tecniche e processi fra indagine e progetto nel territorio di Portovenere. Milano: Politecnico di Milano. <http://hdl.handle.net/l0589/|48286>.

Casey Reas, Chandler McWilliams, LUST (20 I 0). Form + Code in Design, Art and Architecture. New York: Princeton Architectural Press.

Garber Richard (20I4). BIM DESIGN, realising the creative potential of building information modelling. Chichester: John Wiley \& Sons Ltd.

Hemmerling Marco, Cocchiarella Luigi (a cura di). (2018). Informed architecture Computational Strategies in Architectural Design. Cologne: Springer.

McDermott (2018). The PBR guide, a handbook for physically based rendering. 深圳: Allegorithmic SAS

Vulpiani Angelo (20।8). Caso, probabilità e complessità. Roma: Ediesse.

Author

Matteo Cavaglià, Politecnico di Milano, cavaglia.matteo.main@gmail.com

To cite this chapter: Cavaglià Matteo (2020). Imparare dalla rappresentazione digitale del paesaggio, tra suggestioni 'romantiche' e rigore matematico/Learning from the digital representation of the landscape, between 'romantic' suggestion and mathematical rigor. In Arena A., Arena M. Brandolino R.G., Colistra D., Ginex G., Mediati D., Nucifora S., Raffa P. (a cura di). Connettere. Un disegno per annodare e tessere. Atti del $42^{\circ}$ Convegno Internazionale dei Docenti delle Discipline della Rappresentazione/Connecting. Drawing for weaving relationships. Proceedings of the 42 th International Conference of Representation Disciplines Teachers. Milano: FrancoAngeli, pp. 276-295 